\title{
Adaptation of the Kinetics of Glucose Transport to Environmental Conditions in the Yeast Candida utilis CBS 621: a Continuous-culture Study
}

\author{
By ERIK POSTMA, W. ALEXANDER SCHEFFERS* AND \\ JOHANNES P. VAN DIJKEN \\ Department of Microbiology and Enzymology, Delft University of Technology, Julianalaan 67, \\ 2628 BC Delft, The Netherlands
}

(Received 4 November 1987; revised 21 December 1987)

\begin{abstract}
The relation between the kinetic parameters of glucose transport and the physiology of Candida utilis CBS 621 was studied in chemostat cultures. In glucose-limited cultures the transport parameters were dependent on the growth rate of the yeast. Three different transport systems were found which differed by an order of magnitude in their affinity constants, namely a highaffinity $\left(K_{\mathrm{m}} 25 \mu \mathrm{M}\right)$, a medium-affinity $\left(K_{\mathrm{m}} 190 \mu \mathrm{M}\right)$, and a low-affinity uptake system $\left(K_{\mathrm{m}} 2000\right.$ $\mu \mathrm{M})$. Cells growing at a dilution rate of $0.45 \mathrm{~h}^{-1}$ or less had the high-and medium-affinity uptake systems. At a dilution rate of $0.52 \mathrm{~h}^{-1}$ the high-affinity system was absent and both the mediumand low-affinity systems were present. At a dilution rate close to $\mu_{\max }\left(0.57 \mathrm{~h}^{-1}\right)$ only the lowaffinity system was detected. The in situ contribution of each of the transport systems to glucose consumption in glucose-limited cultures was estimated on the basis of their kinetic parameters $\left(K_{\mathrm{m}}\right.$ and $V_{\text {max }}$ ) and the residual glucose concentration in these cultures. The sum of the calculated rates of transport corresponded to the in situ rate of glucose consumption by the cultures as determined from the yield constant and the dilution rate. The dependence of the transport parameters on the growth rate and hence on the environmental sugar concentration was also evident in cells grown under nitrogen limitation. In contrast to carbon-limited cells, nitrogenlimited cultures growing at $D=0.15 \mathrm{~h}^{-1}$ did not exhibit the high-affinity glucose uptake system, whereas the medium- and low-affinity systems were present.
\end{abstract}

\section{INTRODUCTION}

Glucose can be transported into yeasts via three different uptake mechanisms: by facilitated diffusion (Romano, 1982); by active transport through a proton-glucose symporter as shown for species of Candida (Spencer-Martins \& van Uden 1985a) and Rhodosporidium (Hauer \& Höfer, 1982; Höfer \& Misra, 1978); or by a group translocation process in which the glucose is phosphorylated during transport (van Steveninck et al., 1985). In a variety of cases the dependence of the rate of transport on the assay sugar concentration yielded a biphasic kinetic plot indicating the presence of two uptake systems (Bisson \& Fraenkel, 1983; Spencer-Martins \& van Uden, 1985a; van den Broek et al., 1986).

A comparison between the results of different studies in quantitative terms is complicated by the fact that in nearly all cases cells from batch cultures have been studied. Frequently even shake-flask cultures have been used. In such cultures growth is intrinsically oxygen-limited and leads to ethanol production (Rieger et al., 1983; van Dijken \& Scheffers, 1986). As a result, at the time of harvesting, cells to be used for assays of glucose transport may even be growing on ethanol.

Apart from the oxygen concentration, the glucose concentration is also a decisive parameter for sugar metabolism in yeasts. Yeasts which exhibit a Crabtree effect, such as Saccharomyces cerevisiae, perform alcoholic fermentation in the presence of excess sugar despite a sufficient 
supply of oxygen (van Dijken \& Scheffers, 1986). Under these conditions many respiratory enzymes, and transport systems as well, are subject to catabolite repression (Busturia \& Lagunas, 1985, 1986; Spencer-Martins \& van Uden, 1985a,b). It is thus not surprising that different results have been obtained in transport studies with yeast species grown in batch culture.

The advantages of using continuous cultures rather than batch cultures are several: not only are the conditions well defined and easily reproduced, but cells can also be grown at low sugar concentrations, thus avoiding catabolite repression. In this study we have quantified the kinetic parameters of glucose transport in the yeast Candida utilis grown in a chemostat. The results reveal that three different transport systems, all under environmental control, may be present in this yeast.

\section{METHODS}

Micro-organism and growth conditions. Candida utilis CBS 621 was maintained on malt-agar slopes. The organism was grown at $30^{\circ} \mathrm{C}$ in a laboratory fermenter with a 1 litre working volume. The dissolved-oxygen tension was recorded with a steam-sterilizable Clark-type oxygen electrode, and was kept above $50 \%$ air saturation. The $\mathrm{pH}$ was controlled by automatic addition of $2 \mathrm{M}-\mathrm{KOH}$. The medium was prepared according to Bruinenberg et al. (1983). The organism was grown under glucose limitation $\left(S_{\mathrm{r}} 5 \mathrm{~g}^{-1}\right)$ with ammonium as the nitrogen source, or under ammonium limitation $\left(S_{\mathrm{r}} 0.4 \mathrm{~g} \mathrm{l}^{-1}\right)$ with glucose as the carbon source $\left(S_{\mathrm{r}} 5 \mathrm{~g}^{-1}\right)$, or under glutamate limitation (carbon limitation without ammonium) $\left(S_{\mathrm{r}} 5 \mathrm{~g}^{-1}\right)$.

Measurements of residual free-glucose concentration in continuous culture. Cells were rapidly (within $3 \mathrm{~s}$ ) transferred from the culture into liquid nitrogen. The frozen cell suspension was thawed to $0{ }^{\circ} \mathrm{C}$ at room temperature, and then centrifuged in an Eppendorf Microcentaur centrifuge at $4{ }^{\circ} \mathrm{C}(2 \mathrm{~min}, 13000$ r.p.m. $)$. The glucose concentration in the supernatant was determined with a Boehringer glucose kit (enzymic hexokinase/ glucose-6-phosphate dehydrogenase/UV method).

Binding of glucose to cells and filters. In order to estimate substrate binding to cells, the cells were killed by heating. This procedure was adopted since dilution of untreated cells at zero-time (Konings \& Freese, 1972), followed by addition of labelled substrate, gave higher binding values, probably due to high metabolic activity. Also blocking metabolic activity by fixation in $2 \mathrm{M}$-trichloroacetic acid (TCA) resulted in increased binding.

A cell suspension $(10 \mathrm{ml})$ was cooled on ice for $5 \mathrm{~min}$ and put in a boiling water-bath for $1 \mathrm{~min}$, or $2 \mathrm{~min}$ for nitrogen-limited cultures, and rapidly cooled on ice. After this procedure no endogenous oxygen consumption could be observed in a biological oxygen monitor, nor was glucose-dependent oxygen uptake detectable. This procedure yielded cells without apparent changes in the structure of cell wall or plasmalemma as observed by light and electron microscopy. Furthermore, no protein was released from the cells as a result of this treatment. Binding was determined at the desired glucose concentration in duplicate; in all cases it was a linear function of the glucose concentration.

Transport assay. Cells were harvested from the continuous culture and directly used for transport experiments. At high dilution rates $\left(D>0.4 \mathrm{~h}^{-1}\right)$ the cells were washed ( $1 \mathrm{~min}, 3000$ r.p.m.; bench centrifuge), and resuspended in mineral salts solution [ $5 \mathrm{~g}\left(\mathrm{NH}_{4}\right)_{2} \mathrm{SO}_{4} \mathrm{I}^{-1}, 3 \mathrm{~g} \mathrm{KH}_{2} \mathrm{PO}_{4} \mathrm{l}^{-1}, 0.5 \mathrm{~g} \mathrm{MgSO}_{4} .7 \mathrm{H}_{2} \mathrm{Ol}^{-1}$, $\mathrm{pH}$ ] ] to give the same optical density as the original culture. Nitrogen-limited cultures were washed twice following the same procedure. Uptake experiments were done within $30 \mathrm{~min}$ of harvesting (washing) of the cells. During the experiments the cells were aerated by rapid magnetic stirring at room temperature. Cell suspension $\left(100 \mu 1 ; 2.5 \mathrm{~g}\right.$ dry weight $\left.1^{-1}\right)$ was added to flat-bottom glass tubes (diameter $1 \mathrm{~cm}$, height $3 \mathrm{~cm}$ ), and placed in a thermostated metal block with a magnetic stirrer $\left(30^{\circ} \mathrm{C}\right)$. During the uptake experiments the cell suspension was rapidly stirred by $7 \mathrm{~mm}$ long Teflon stirrer bars. After temperature equilibration for $2 \mathrm{~min}$ the reaction was started by addition of the labelled substrate $\left(\left[\mathrm{U}^{-14} \mathrm{C}\right]\right.$ glucose; $\left.3 \mathrm{mCi} \mathrm{mmol}^{-1}\left[111 \mathrm{MBq}^{\mathrm{mmol}}{ }^{-1}\right]\right)$. The reaction was stopped by dilution of the suspension with $2 \mathrm{ml} 0.1 \mathrm{M}-\mathrm{LiCl}$ at $4{ }^{\circ} \mathrm{C}$, and the mixture was filtered (nitrocellulose; $0.45 \mu \mathrm{m}$ pore size, $35 \mathrm{~mm}$ diameter) within $5 \mathrm{~s}$. The filters were washed with $2 \mathrm{ml} 0 \cdot 1 \mathrm{M}-\mathrm{LiCl}$ at $4{ }^{\circ} \mathrm{C}$, and put in glass scintillation vials with $5 \mathrm{ml}$ scintillation fluid (Emulsifier Scintillator 299). After $30 \mathrm{~min}$ (clearing of filters) the radioactivity was measured in a Beckman LS 3801 bench-top scintillation counter. In all experiments the mean of three $5 \mathrm{~s}$ replicate analyses was determined. The statistical variation in the determination of each point is approximately $20 \%$. Hanes plots were based on the mean of three independent measurements at each single substrate concentration (Hanes, 1932). In all cases the rate of uptake was proportional to the cell density between 0.4 and $2 \cdot 5 \mathrm{~g}$ dry wt $\mathrm{l}^{-1}$.

Hexokinase assay. Cells were harvested from continuous culture, washed once with buffer (10 mm-potassium phosphate, pH 7.5, 2 mM-EDTA), concentrated 5-fold in sonication buffer [100 mM-potassium phosphate, $\mathrm{pH} \mathrm{7.5,}$ $2 \mathrm{mM}-\mathrm{MgCl}_{2}, 2 \mathrm{mM}$-dithiothreitol (DTT)], and sonicated at $0^{\circ} \mathrm{C}$ in an MSE $150 \mathrm{~W}$ sonicator. Cell debris was removed by centrifugation ( $15 \mathrm{~min}, 20000$ r.p.m.; Sorvall $\mathrm{RC}-5 \mathrm{~B}$ centrifuge, SS-34 rotor). The assay mixture contained (in a final volume of $1 \mathrm{ml}$ ): hexokinase (EC 2.7.1.1); imidazole/ $\mathrm{HCl}$ buffer, $50 \mathrm{mM}, \mathrm{pH} 7 \cdot 6$; $\mathrm{NADP}^{+}$, 
$1 \mathrm{mM} ; \mathrm{MgCl}_{2}, 10 \mathrm{~mm}$; and glucose-6-phosphate dehydrogenase, $50 \mathrm{U}$. Absorption was measured at $340 \mathrm{~nm}$ on a Hitachi model 100-60 spectrophotometer.

Dry weight of cultures. This was determined by weighing appropriate samples after filtration on membrane filters (Millipore; $0.45 \mu \mathrm{m}$ pore size), and drying at $80^{\circ} \mathrm{C}$.

Protein determination. This was done by the method of Lowry, using bovine serum albumin as standard.

Electron microscopy of cells. This was done as described by Smith \& Batenburg-van der Vegte (1985).

Chemicals. $\left[\mathrm{U}^{-14} \mathrm{C}\right] \mathrm{Glucose}\left[3 \mathrm{mCi} \mathrm{mmol}^{-1}\left(111 \mathrm{MBq} \mathrm{mmol}^{-1}\right)\right]$ was obtained from Amersham. All other chemicals were obtained from commercial sources at the highest purity available.

\section{RESULTS}

Residual glucose concentration in glucose-limited cultures

Since in glucose-limited chemostat cultures the rate of sugar consumption, and hence the rate of sugar transport, is a function of the residual glucose concentration in the culture, measuring this parameter was a prerequisite for an evaluation of transport kinetics. This required rapid sampling and rapid fixation in order to avoid interference by the high metabolic activity of the cells. Fixation of samples in liquid nitrogen followed by thawing at $0{ }^{\circ} \mathrm{C}$ and centrifugation at $4{ }^{\circ} \mathrm{C}$ proved to be an adequate method. This was evident from the fact that, in accordance with continuous-culture kinetics, the residual glucose concentration at a particular dilution rate was independent of the reservoir concentration in the culture (results not shown). This latter parameter should have affected the residual glucose concentration if the sampling and/or fixation procedures had been inadequate.

The residual glucose concentration in glucose-limited chemostat cultures of $C$. utilis followed classical Monod kinetics (Herbert et al., 1956; Table 1). The apparent affinity constant for glucose and the $\mu_{\max }$ of the organism were determined from a plot of $s$ versus $s . D^{-1}$ (Hanes, 1932). From the slope of the line a $K_{\mathrm{s}}$ of $15 \mu \mathrm{M}$ and, from the intercept with the $x$-axis, a $\mu_{\max }$ of $0.595 \mathrm{~h}^{-1}$ were calculated. From wash-out experiments a $\mu_{\max }$ of $0.585 \mathrm{~h}^{-1}$ was determined, in good agreement with the calculated value and showing the reliability of the method used to measure the residual glucose concentration.

\section{Measurement of kinetic parameters of glucose transport}

Inherent to in vivo studies of transport is the interference caused by subsequent metabolism of the substrate. In order to avoid this problem substrate analogues have frequently been used to obtain information on the kinetics of transport in vivo (Kotyk \& Michaljaničová, 1978; Jaspers \& van Steveninck, 1975; Barnett \& Sims, 1976b; Meredith \& Romano, 1977; Franzusoff \& Cirillo, 1982; van den Broek et al., 1986). Apart from the fact that such studies can only yield qualitative information with respect to the uptake of the real substrate, it must be emphasized that the results obtained with substrate analogues do not always mimic changes in the transport parameters of the real substrate (Barnett $\&$ Sims, 1976 b). It was therefore decided to use glucose itself in assays of transport kinetics. The interference of metabolism with transport kinetics was studied by following the time-dependent accumulation of radioactivity in cell suspensions incubated with $\left[\mathrm{U}-{ }^{14} \mathrm{C}\right]$ glucose. Incubation times of less than $10 \mathrm{~s}$ yielded transport rates that were linearly proportional to time. After $10 \mathrm{~s}$ the uptake rate decreased, probably due to metabolic activity of cells and decreasing external glucose concentration (Fig. 1). Therefore in all experiments a $5 \mathrm{~s}$ incubation time was used for the determination of the initial rate of uptake.

Cells grown at low dilution rate could be used for the assays without further treatment, since at the time of the assay (approximately $5 \mathrm{~min}$ after harvesting), the residual glucose concentration was below detection level, and hence did not interfere. However, with cultures grown at high dilution rates washing of cells was required due to the interference of high residual substrate concentrations. In order to assess the effect of washing of cells on transport kinetics, glucose uptake by cells grown at low dilution rate and assayed after or without washing steps was studied. It appeared (results not shown) that this pretreatment had no effect on the kinetic parameters of glucose uptake. It was therefore assumed that this also held for cells grown at high dilution rates. 


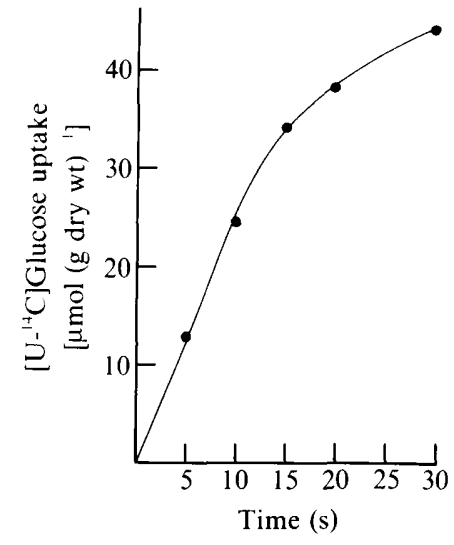

Fig. 1

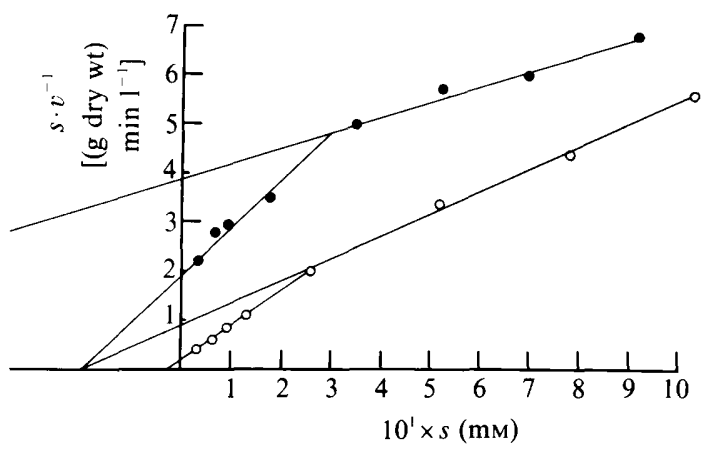

Fig. 2

Fig. 1. Uptake of $\left[\mathrm{U}^{-14} \mathrm{C}\right] \mathrm{glucose}$. Cells from a glucose-limited continuous culture growing at a dilution rate of $0.3 \mathrm{~h}^{-1}$ were incubated with $175 \mu \mathrm{M}$-glucose.

Fig. 2. Hanes plot of the kinetics of $\left[\mathrm{U}^{-14} \mathrm{C}\right.$ ]glucose transport by cells from a glucose-limited culture growing at $D=0.1 \mathrm{~h}^{-1}(O)$ and $D=0.52 \mathrm{~h}^{-1}(O)$. The intercept with the $x$-axis gives the substrate affinity constant $\left(K_{\mathrm{m}}\right)$ and the slope equals $1 / V_{\max }$.

Table 1. Apparent affinities of glucose uptake by cells grown at different dilution rates in glucose-limited chemostat cultures

$$
K_{\mathrm{m}}(\text { low })=25 \pm 5 \mu \mathrm{M} ; K_{\mathrm{m}}(\text { medium })=190 \pm 25 \mu \mathrm{M} ; K_{\mathrm{m}}(\text { high })=2000 \pm 500 \mu \mathrm{M}
$$

Apparent affinity of glucose uptake $(\mu \mathrm{M})$

$\begin{array}{ccccc}\begin{array}{c}\text { Dilution } \\ \text { rate } h^{-1}\end{array} & \begin{array}{c}\text { Glucose } \\ \text { concn }(\mu \mathrm{M})\end{array} & \begin{array}{c}\text { High-affinity } \\ \text { carrier }\end{array} & \begin{array}{c}\text { Medium-affinity } \\ \text { carrier }\end{array} & \begin{array}{c}\text { Low-affinity } \\ \text { carrier }\end{array} \\ 0 \cdot 1 & 3 & 25 & 195 & - \\ 0 \cdot 2 & 8 & 23 & 195 & - \\ 0 \cdot 3 & 13 & 23 & 190 & - \\ 0 \cdot 35 & 18 & 25 & 160 & - \\ 0 \cdot 38 & 29 & 27 & 165 & - \\ 0 \cdot 40 & 40 & 25 & 200 & - \\ 0 \cdot 43 & 70 & 20 & 180 & - \\ 0 \cdot 45 & 95 & 25 & 200 & 2100 \\ 0 \cdot 52 & 180 & - & 200 & 1950 \\ 0 \cdot 57 & 330 & - & - & \end{array}$

Kinetic parameters of glucose transport in glucose-limited cultures

Considerable differences were noted between the kinetic constants of glucose uptake in cells growing at low dilution rate $\left(D=0 \cdot 1 \mathrm{~h}^{-1}\right)$, and those of cells growing at high dilution rate $\left(D=0.52 \mathrm{~h}^{-1}\right)$. In both cases Hanes plots were biphasic, indicating the presence of two transport systems with different affinities (Fig. 2). At $D=0.1 \mathrm{~h}^{-1}$ the affinity constants were 25 and $190 \mu \mathrm{M}$ whereas at the high dilution rate values of 190 and $2000 \mu \mathrm{M}$ were calculated (Fig. 2). This prompted a more detailed study of the relation between the kinetics of glucose uptake and the dilution rate (Table 1, Fig. 3). At dilution rates below $0.52 \mathrm{~h}^{-1}$ Hanes plots revealed two affinity constants of 25 and $190 \mu \mathrm{M}$. Above this dilution rate the high-affinity system was absent, but instead a low-affinity system was detectable together with the medium-affinity system. This latter system was absent at a dilution rate of $0.57 \mathrm{~h}^{-1}$ and only one low-affinity constant was estimated from a Hanes plot (Table 1). 


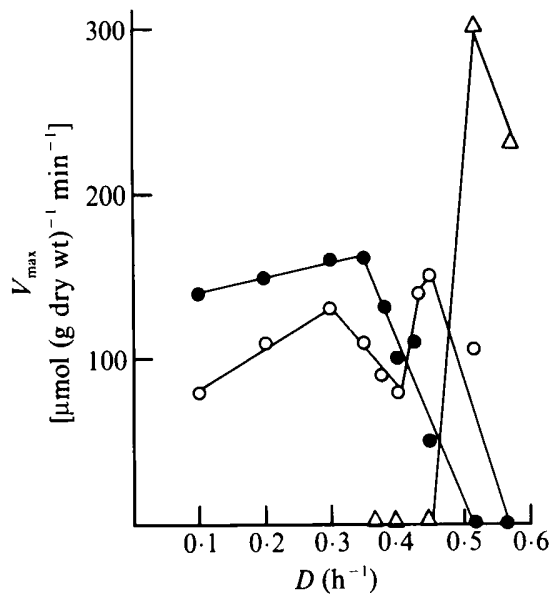

Fig. 3

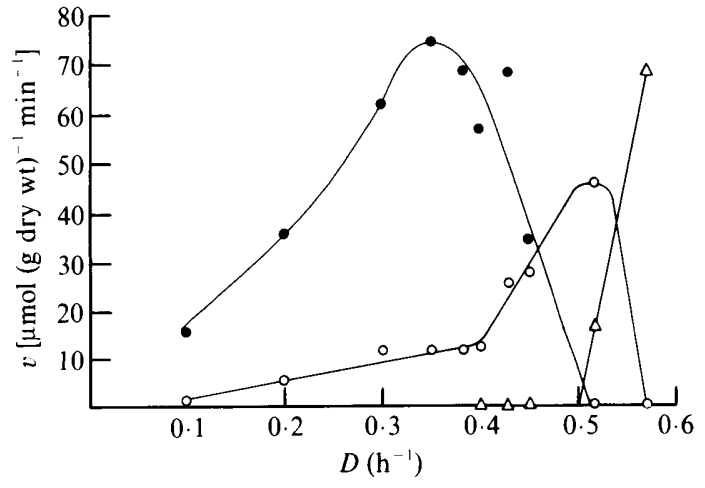

Fig. 4

Fig. 3. Capacity $\left(V_{\max }\right)$ of the individual carriers as obtained from the slopes of the Hanes plots at different dilution rates of glucose-limited cultures $\bigcirc, 25 \mu \mathrm{M} ; \bigcirc, 190 \mu \mathrm{M} ; \triangle, 2000 \mu \mathrm{M}$.

Fig. 4. In situ uptake rate of glucose at different dilution rates of the individual glucose carriers as calculated from the free substrate concentration in the fermenter and from transport parameters. $25 \mu \mathrm{M} ; \bigcirc, 190 \mu \mathrm{M} ; \triangle, 2000 \mu \mathrm{M}$.

The capacity, that is the $V_{\max }$ of each of the three uptake systems as a function of the dilution rate is presented in Fig. 3. Both the high- and the medium-affinity system increased in capacity with the increase in dilution rate up to approximately $0 \cdot 3-0.35 \mathrm{~h}^{-1}$. Above this dilution rate the capacity of the high-affinity system decreased and was absent at $D=0.52 \mathrm{~h}^{-1}$. The mediumaffinity system also decreased above $D=0.3 \mathrm{~h}^{-1}$ but increased at dilution rates between 0.4 and $0.5 \mathrm{~h}^{-1}$. Above $D=0.45 \mathrm{~h}^{-1}$ the capacity of the medium-affinity system decreased and a lowaffinity system became apparent (Fig. 3).

\section{Estimation of the kinetics of glucose uptake in the chemostat}

From the results presented above it is evident that more than one uptake system may be present in cells from steady-state cultures that are glucose-limited. The capacity of each of these systems is apparently correlated to the dilution rate and hence the glucose concentration. In order to evaluate this correlation, the contribution of each of the carrier systems to the in situ glucose uptake rate was calculated from the kinetic parameters and the residual substrate concentration at a particular dilution rate according to

$$
v_{(\text {in situ) }}=\frac{V_{\max } \cdot s_{(i n \text { situ })}}{K_{\mathrm{m}}+s_{(\text {in situ })}}
$$

The in situ rate of transport by each of the three systems is shown in Fig. 4. It is apparent that the high-affinity system is the most prominent at low dilution rates. At higher dilution rates, where the activity of the high-affinity system is decreasing, the medium-affinity system becomes dominant $\left(0.45-0.52 \mathrm{~h}^{-1}\right)$, whereas at dilution rates above $0.52 \mathrm{~h}^{-1}$ the low-affinity system accounts for more than $50 \%$ of the total glucose transported. The sum of the rates of the individual systems is shown in Fig. 5. The calculated overall rate of glucose transport is close to the estimated rate based on the overall growth kinetics:

Specific rate of glucose consumption $=$ maintenance rate + dilution rate $\cdot$ cell yield $^{-1}$

\section{Possible effects of metabolism on transport parameters}

Previous studies have shown that hexokinases may play a role in glucose uptake in yeasts, and particularly in Saccharomyces cerevisiae (Meredith \& Romano, 1977; Bisson \& Fraenkel, 1983; 


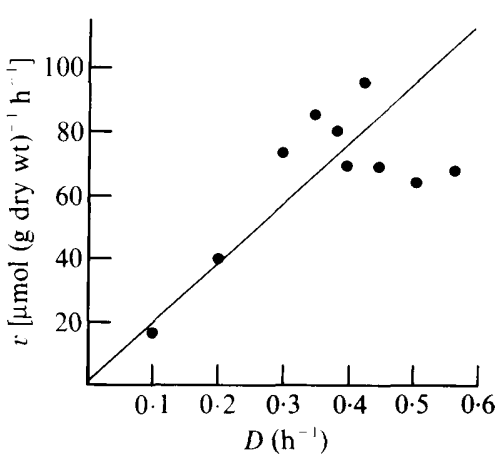

Fig. 5

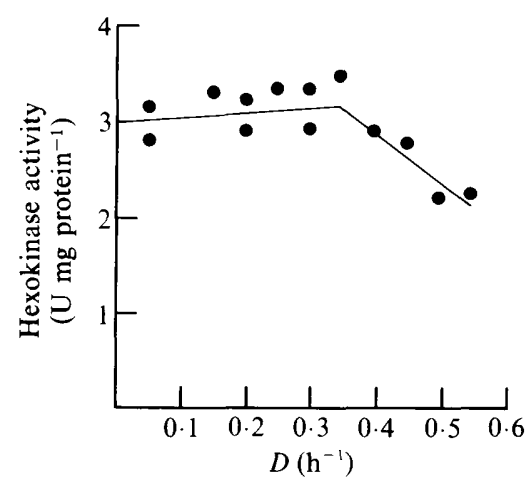

Fig. 6

Fig. 5. Sum of the individual fluxes of glucose via the three carriers as a function of the dilution rate $\left(h^{-1}\right)$. The solid line represents the glucose uptake rate calculated from a maintenance energy of $2.3 \mu \mathrm{mol} \mathrm{g}^{-1} \mathrm{~min}^{-1}$ (Atkinson \& Mavituna, 1983) and a mean growth yield of $0.5 \mathrm{~g}$ cells $\left(\mathrm{g}\right.$ glucose) ${ }^{-1}$.

Fig. 6. Hexokinase activity in extracts of cells of $C$. utilis as a function of the dilution rate in glucoselimited cultures.

Table 2. Apparent substrate affinities $\left(K_{m}\right)$ and transport capacities $\left(V_{\max }\right)$ of nitrogen- and glutamate-limited cultures at different dilution rates in continuous culture

Nitrogen limitation was at an $\left(\mathrm{NH}_{4}\right)_{2} \mathrm{SO}_{4}$ : glucose ratio of $8: 100(\mathrm{w} / \mathrm{w})$. The statistical variation is specified in Methods.

\begin{tabular}{|c|c|c|c|c|c|c|c|c|}
\hline & & $\mathrm{m}(\mathrm{m})$ & & {$[\mu \mathrm{mol}$} & $\begin{array}{l}V_{\max } \\
\text { cells) }\end{array}$ & $\operatorname{in}^{-1}$ ] & & Glucose \\
\hline Carrier* ... & 1 & 2 & 3 & 1 & 2 & 3 & $\left(h^{-1}\right)$ & $(\mu \mathrm{M})$ \\
\hline Nitrogen-limited & - & 175 & 1300 & - & 25 & 35 & $0 \cdot 15$ & 2500 \\
\hline Glucose-limited & 25 & 195 & - & 140 & 90 & - & $0 \cdot 10$ & 3 \\
\hline Glutamate-limited & 30 & 195 & - & 100 & 90 & - & $0 \cdot 10$ & 0 \\
\hline Glucose-limited & 23 & 195 & - & 150 & 130 & - & $0 \cdot 20$ & 8 \\
\hline
\end{tabular}

- , Transport system not detectable.

*1, High-affinity carrier; 2, medium-affinity carrier; 3, low-affinity carrier.

Franzusoff \& Cirillo, 1982; van Steveninck et al., 1985). The possibility that the observed changes in the kinetics of glucose transport may be explained by changes in hexokinase activities was investigated (Fig. 6). At low dilution rates the total activity of hexokinases was relatively constant but decreased at higher dilution rates. At all dilution rates tested the $K_{\mathrm{m}}$ for either glucose or ATP did not change: $K_{\mathrm{m}}$ (glucose) $=180 \pm 10 \mu \mathrm{M}$ and $K_{\mathrm{m}}$ (ATP) $=$ $110 \pm 10 \mu \mathrm{M}$. Although it is intrinsically impossible to exclude the effect of subsequent metabolism on transport kinetics, the above results make it unlikely that our results can be explained at the level of sugar phosphorylation.

\section{Transport parameters of nitrogen- and glutamate-limited cultures}

The results clearly show that the kinetic parameters of glucose transport in $C$. utilis are a function of the residual substrate concentration in the culture. This is also evident from a comparison of the transport parameters of a glucose-limited culture and those of a nitrogenlimited culture at the same dilution rate (Table 2). The higher residual glucose concentration in the nitrogen-limited culture apparently triggered the synthesis of the low-affinity system and simultaneously the synthesis of the high-affinity system was repressed. In glutamate-limited cultures the $25 \mu \mathrm{M}$ and $190 \mu \mathrm{M}$ systems could be observed. It can thus be concluded that the transport systems are regulated by a repression/derepression mechanism. 
Table 3. Kinetic parameters of glucose transport in different yeasts as obtained from the literature

\begin{tabular}{|c|c|c|c|}
\hline Organism & $\underset{(\mathrm{mM})}{\text { Affinity }\left(K_{\mathrm{m}}\right)}$ & $\begin{array}{c}\text { Capacity }\left(V_{\max }\right) \\
{\left[\mu \mathrm{mol}(\mathrm{g} \text { cells })^{-1} \min ^{-1}\right]}\end{array}$ & Reference \\
\hline $\begin{array}{l}\text { Saccharomyces } \\
\text { cerevisiae }\end{array}$ & $\begin{array}{l}7 \cdot 6 \\
1.9 * \\
20 \\
1.5 \\
1.6\end{array}$ & $\begin{array}{l}100 \\
2 * \dagger \\
75 \ddagger \\
75 \pm \\
-\end{array}$ & $\begin{array}{l}\text { Barnett \& Sims }(1976 b) \\
\text { Romano (1982) } \\
\text { Bisson \& Fraenkel (1983) } \\
\text { Meredith \& Romano (1977) }\end{array}$ \\
\hline Candida parapsilosis & $2 \cdot 1^{*}$ & $17^{*}$ & Kotyk \& Michaljaničová (1978) \\
\hline Candida utilis & $\begin{array}{l}10 \\
0 \cdot 17\end{array}$ & $\begin{array}{l}40 \\
1.9\end{array}$ & Barnett \& Sims $(1976 a, b)$ \\
\hline Candida wickerhami & $\begin{array}{l}1 \cdot 7 \\
0 \cdot 18\end{array}$ & $\begin{array}{l}27 \dagger \\
32 \dagger\end{array}$ & Spencer-Martins \& van Uden (1985a) \\
\hline $\begin{array}{l}\text { Rhodosporidium } \\
\text { toruloides }\end{array}$ & 0.55 & 17 & Barnett \& Sims $(1976 b)$ \\
\hline \multicolumn{4}{|c|}{$\begin{array}{l}\text {, Value not presented in reference. } \\
\text { * Measured with } 6 \text {-deoxy-D-glucose as the substrate. } \\
\dagger \text { Recalculated from data. } \\
\ddagger \text { Recalculated from data on the assumption that } 5 \mathrm{~g} \text { wet wt } \equiv 1 \mathrm{~g} \text { dry wt. }\end{array}$} \\
\hline
\end{tabular}

As well as the glucose-limited cultures, the nitrogen-limited culture also had an in situ rate of glucose consumption which matched the calculated rate of glucose consumption.

\section{DISCUSSION}

The results of our chemostat studies with $C$. utilis reveal that in this organism the kinetics of glucose transport are adapted to the residual concentration via a well-balanced synthesis of three transport systems (Table 1, Fig. 3) which are characterized by their affinity constants. The capacity, i.e. the $V_{\max }$ of these systems, reached high values, namely 130,160 and $300 \mu \mathrm{mol}(\mathrm{g}$ cells) ${ }^{-1} \min ^{-1}$, for the high-, medium- and low-affinity transport systems respectively. These values are much higher than the $V_{\max }$ values obtained with Candida species so far (Table 3). This can be explained by the cultivation conditions. In batch cultures, which have been used in most transport studies, the glucose concentration is saturating for the glucose transport systems during exponential growth. In glucose-limited chemostat cultures, on the other hand, cells are grown at glucose concentrations which are limiting for these systems.

The medium- and low-affinity uptake systems have been reported previously for Candida species (Table 3), but the occurrence of a transport system with a $K_{\mathrm{m}}$ of $25 \mu \mathrm{M}$ has so far not been described. This uptake system allows growth of $C$. utilis at very low glucose concentrations corresponding to low dilution rates.

It is evident that the glucose concentration in the culture is a decisive parameter in the regulation of the synthesis of the three transport systems. However, not only the extracellular glucose concentration but also the physiological status of the cells is of importance for the capacity $\left(V_{\max }\right)$ of the three transport systems. This is evident from a comparison of the results obtained with cells growing at high dilution rate under glucose limitation and those obtained with cells growing under nitrogen limitation at a low dilution rate. In both cases the high external glucose concentrations resulted in low-affinity constants but the low growth rate of the nitrogen-limited culture caused low $V_{\max }$ values as compared to those of glucose-limited cultures. This specific induction of carriers in response to glucose concentration has been found previously with stationary phase cultures of yeasts (no glucose present). In that case also carriers with higher affinity for glucose were induced (Spencer-Martins \& van Uden, 1985a; van den Broek et al., 1986) (Table 3). The physiological rationale of introducing different carriers at different external glucose concentrations remains as yet unclear. Cells probably would easily 
survive with only a high-affinity system by adjusting its capacity. The answer probably is that the different carriers have different energy requirements (e.g. $\mathrm{H}^{+}$-stoichiometries) that make a system with a lower affinity preferable at higher external glucose concentrations.

\section{REFERENCES}

AtKinson, B. \& Mavituna, F. (1983). Biochemical Engineering and Biotechnology Handbook, p. 146. Byfleet, Surrey: Macmillan/Globe Book Services.

Barnett, J. A. \& Sims, A. P. $(1976 a)$. A note on the kinetics of uptake of D-glucose by the food yeast, Candida utilis. Archives of Microbiology 111, 193-194.

Barnett, J. A. \& Sims, A. P. (1976b). Some physiological observations on the uptake of D-glucose and 2-deoxy-D-glucose by starving and exponentially-growing yeasts. Archives of Microbiology 11, $185-192$

Bisson, L. F. \& Fraenkel, D. G. (1983). Involvement of kinases in glucose and fructose uptake by Saccharomyces cerevisiae. Proceedings of the National Academy of Sciences of the United States of America 80, 1730-1734.

van DEN Broek, P. J. A., Schuddemat, J., Van Leeuwen, C. C. M. \& VAN SteveninCK, J. (1986). Characterization of 2-deoxyglucose and 6-deoxyglucose transport in Kluyveromyces marxianus: evidence for two different transport mechanisms. Biochimica et biophysica acta 860, 626-631.

BruinenberG, P. M., van DiJken, J. P. \& SCheffers, W. A. (1983). An enzymic analysis of NADPH production and consumption in Candida utilis. Journal of General Microbiology 129, 965-971.

Busturia, A. \& Lagunas, R. (1985). Identification of two forms of the maltose transport system in Saccharomyces cerevisiae and their regulation by catabolite inactivation. Biochimica et biophysica acta 820, 324-326.

Busturia, A. \& Lagunas, R. (1986). Catabolite inactivation of the glucose transport system in Saccharomyces cerevisiae. Journal of General Microbiology 132, 379-385.

van Dijken, J. P. \& Scheffers, W. A. (1986). Redox balances in the metabolism of sugars by yeasts. FEMS Microbiology Reviews 32, 199-224.

Franzusoff, A. \& Cirillo, V. P. (1982). Uptake and phosphorylation of 2-deoxy-D-glucose by wild-type and single-kinase strains of Saccharomyces cerevisiae. Biochimica et biophysica acta 688, 295-304.

Hanes, C. S. (1932). Studies on plant amylases. 1. The effect of starch concentration upon the velocity of hydrolysis by the amylase of germinated barley. Biochemical Journal 26, 1406-1421.

HAUER, R. \& HÖFER, M. (1982). Variable $\mathrm{H}^{+} /$substrate stoicheiometries in Rhodotorula gracilis are caused by a $\mathrm{pH}$-dependent protonation of the carrier(s). Biochemical Journal 208, 459-464.
Herbert, D., Elsworth, R. \& Telling, R. C. (1956). The continuous culture of bacteria; a theoretical and experimental study. Journal of General Microbiology 14, 601-622.

HöFER, M. \& MisRa, P. C. (1978). Evidence for a proton/sugar symport in the yeast Rhodotorula gracilis (glutinis). Biochemical Journal 172, 15-22.

JASPERS, H. T. A. \& VAN STEVeninck, J. (1975). Transport-associated phosphorylation of 2-deoxy-Dglucose in Saccharomyces fragilis. Biochimica et biophysica acta 406, 370-385.

Konings, W. N. \& Freese, E. (1972). Amino acid transport in membrane vesicles of Bacillus subtilis. Journal of Biological Chemistry 247, 2408-2418.

KotyK, A. \& Michaljaničová, D. (1978). Transport kinetics of 6-deoxy-D-glucose in Candida parapsilosis. Folia microbiologica 23, 18-26.

Meredith, S. A. \& Romano, A. H. (1977). Uptake and phosphorylation of 2-deoxy-D-glucose by wild type and respiration-deficient bakers' yeast. Biochimica et biophysica acta 497, 745-759.

Rieger, M., KäpPELI, O. \& Fiechter, A. (1983). The role of limited respiration in the incomplete oxidation of glucose by Saccharomyces cerevisiae. Journal of General Microbiology 129, 653-661.

Romano, A. H. (1982). Facilitated diffusion of 6deoxy-D-glucose in bakers' yeast: evidence against phosphorylation-associated transport of glucose. Journal of Bacteriology 152, 1295-1297.

SMith, M. Th. \& Batenburg-VAN DER Vegte, W. $H$. (1985). Ultrastructure of septa in Blastobotrys and Sporothrix. Antonie van Leeuwenhoek 51, 121128.

SPENCER-Martins, I. \& VAN Uden, N. (1985a). Catabolite interconversion of glucose transport systems in the yeast Candida wickerhamii. Biochimica et biophysica acta 812, 168-172.

SPENCER-MARTINS, I. \& VAN UdEN, N. (1985b). Inactivation of active glucose transport in Candida wickerhamii is triggered by exocellular glucose. FEMS Microbiology Letters 28, 277-279.

van Steveninck, J., Tiussen, J. P. F., Dubbelman, T. M. A. R. \& VAN DEN Broek, P. J. A. (1985). The role of polyphosphates in sugar transport across the plasma membrane of yeast. In Environmental Regulation of Microbial Metabolism, FEMS Symposium no. 23, pp. 377-384. Edited by I. S. Kulaev, E. A. Dawes \& D. W. Tempest. London \& New York: Academic Press. 